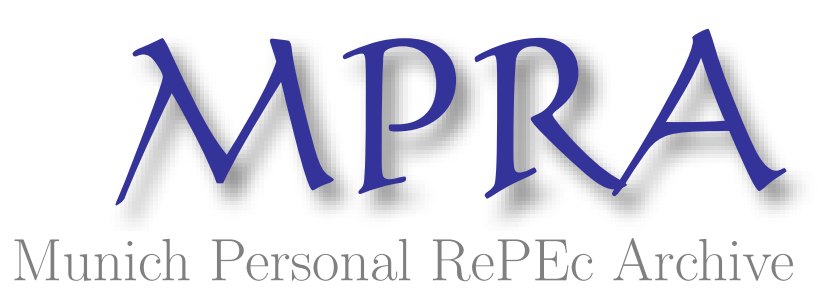

Male Worker Migration and Women
Empowerment: The case of Bihar, India

K.M. Singh and R.K.P. Singh and Anjani Kumar

ICAR-RCER, Patna, ICRISAT, Hyderabad

15. August 2013

Online at http://mpra.ub.uni-muenchen.de/49385/

MPRA Paper No. 49385, posted 30. August 2013 13:46 UTC 


\title{
Male Worker Migration and Women Empowerment: The case of Bihar, India
}

\author{
K M Singh ${ }^{1}$, R K P Singh ${ }^{2}$ and Anjani $\operatorname{Kumar}^{3}$
}

\begin{abstract}
Migration of population has been a recurrent phenomenon since the dawn of human history. Though its form has changed but it remains a dominant event in the global social system. In modern days also people migrate from underdeveloped areas to the developed ones in search of better opportunities. Several theories have been propounded to explain the occurrence of migration. A number of social, cultural, economic, spatial, climatic, demographic factors induce migration. Among them, the economic factors are considered as the primary reasons for inducing migration. Migration of male labour force from Bihar has increased during last two decades which prompted us to analyze its consequences on efficiency of input in agricultural production, livelihood through remittances and also the empowerment of women left behind at place of origin. It was observed that the efficiencies of human labour and irrigation in rice production were higher than non-migrant households and statistically significant, indicating rational use of these two critical inputs on migrant households in Bihar. The migration seems to have helped in judicious use of human labour at native place due to migration of surplus labour force for gainful employment to destination of migration. Remittances have been utilized for meeting consumption needs, improved livelihood, better education to children and better health care facilities which help in overall improvement in livelihood on migrant households in Bihar. Migrant households also preferred to save money to meet their requirements in unforeseen situations. It can thus be infered that migration may be one of risk-coping strategies for the weaker sections of the society and has helped developing the saving habits among migrant households. The allocation of remittances on agricultural inputs could have increased if proper infrastructure facilities were present in rural areas for faster dissemination of modern agricultural technology for increasing agricultural production. Level of women employment has increased on migrant households, particularly on poor households; however, work load of women has also increased. It has been observed that role of women of migrant households changed from unpaid female labour to managers of the household, however, they face problem in management of fund, technology and input-output marketing. There is a need to launch a programme for their training to improve their knowledge in financial, technological and marketing management.
\end{abstract}

Key words: Migration, Women empowerment, Labor migration, Remittances, Bihar

\footnotetext{
${ }^{1}$ Principal Scientist (Agril. Economics) and Head, Division of Socio-economic and Extension, ICAR Research Complex for Eastern Region, Patna, India, Email: m.krishna.singh@ gmail.com

${ }^{2}$ Former Advisor, State Farmer's Commission, Govt. of Bihar, Patna, India

${ }^{3}$ Principal Scientist (Agricultural Economics), International Crops Research Institute for Semi-Arid Tropics, Hyderabad, India
} 


\section{Male Worker Migration and Women Empowerment: The case of Bihar, India}

\section{Introduction}

Migration of population has been a recurrent phenomenon since the dawn of human history. Though its form has changed but it remains a dominant event in the global social system. In modern days also people migrate from underdeveloped areas to the developed ones in search of better opportunities. Several theories have been propounded to explain the occurrence of migration. A number of social, cultural, economic, spatial, climatic, demographic factors induce migration. Among them, the economic factors are considered as the primary reasons for inducing migration.

According to the two sectors growth model of Lewis and others the surplus labour from low productive agriculture in rural areas is transferred to highly productive industrial sector in urban areas for providing needed manpower for the urban industrial growth. But this theory fails to explain an increasing rural migration which increased during last two decades in India, particularly from Bihar. The most effective theory for explaining migration is push and pull theory which states that the migration generally takes place when the positive pull factors at the place of destination are outnumbered by push factors at the place of origin (Bague, 1969). No matter what theory lies behind migration but the phenomenon is considered socially beneficial since the human resources were being shifted from areas where their social marginal products were assumed to be zero to places where their marginal products are not only positive but also rapidly growing as a result of capital accumulation and technological progress. The new economics of migration explains that the decision to migrate is taken by larger association of related people, household or families rather than autonomous individuals. (Stark, 1986). It is rather a type of risk management, done in order to supplement income, through inter-sectoral movement, even in the absence of wage differentials.

The relationship between migration and technological change and production can be viewed in context of two conflicting hypotheses. The first being that out migration stimulates development of the origin area through remittances and by inducing technological changes which ultimately results in higher output and income in the area. Another hypothesis on the contrary 
states that it leads to labour shortages and decline in the average quality of labour which adversely affects output and productivity in native place. Research on migration becomes of outmost priority as its impact both to place of origin and destination has been undermined. The migration from an underdeveloped state like Bihar has increased tremendously in recent years, which are supposed to have far reaching implications on social and economic dimensions of the state. There is dearth of studies which examine labour migration in agriculture sector from place of origin angle. There are far reaching consequences of migration of male labour force on their place of origin. Keeping in view the anticipated consequences of migration in place of origin, this study has been undertaken to examine the impact of male labour out-migration on rice productivity, livelihood and women empowerment on migrant household in Bihar.

\section{Methodology}

The study is based on a survey of 400 households (200 migrants and 200 non-migrants) from eight villages in Madhubani and East Champaran districts of Bihar. Migrant households and matching sample of non-migrant households were selected to undertake a comparative analysis of differences in agricultural productivity parameters and women empowerment level.

The survey was conducted in 2005-06 and detailed information on household characteristics, agricultural production and employment, participation in decision making in farm and non farm activities for both categories of households were collected. However, migration related information including remittance and their use were collected from migrant households. In each household, more detailed information was gathered for two rice plots, including information on inputs and outputs and other characteristics of these plots. In the present study, we restrict our unit of analysis to two plots on which rice was cultivated. Non-linear model (Cobb-Douglas) has been used to find out impact of migration on input efficiencies in production of rice on migrant households. The efficiencies of factors of production have been estimated by following form of function:

\footnotetext{
$\ln Y=\alpha+\beta 1 \ln X 1+\beta 2 \ln X 2+\beta 3 \ln X 3+\beta 4 \ln X 4+\beta \ln X 5+\beta 6 \ln X 6+U$

Where,

$\mathrm{Y}=$ Rice production in quintals

$\mathrm{X}_{1}=$ Area under rice in hectare
} 
$\mathrm{X}_{2}=$ Labor used in rice production (in man days)

$\mathrm{X}_{3}=$ Variable capital in Rs. (for seeds, fertilizer and pesticides)

$\mathrm{X}_{4}=$ Cost of bullock labour in Rs. (owned and hired)

$\mathrm{X}_{5}=$ Expenses on use of machineries in rice production in Rs. (owned thired)

$\mathrm{X}_{6}=$ Irrigation cost in Rs. (owned +hired)

Ordinary Least square estimates of Regression Coefficients ( $\beta$ is) were computed to identify the variables in migrant and non-migrant households which had significant contribution in rice production $(\mathrm{Y})$.

An effort has been made to analyze the impact of male migration on participation of women in decision making process relating to management of agricultural operations, household management, their interaction with different sources of information, and participation in rural institutions. However, their strategies in coping with uncertainties in agriculture and their perceptions on rice and livestock production technology, and benefits from migration have also been examined. The women empowerment is measured by obtaining information through continuum of five score as given below in table-...

Computation of Women Empowerment based on the Decision making situation at Household level for migrant and non-migrant households;

Decision making situation

Score

Women taking decision in presence of male member of household 04

Women taking decision in absence of male family member

Women taking decision with consultation of women of household 02

Women taking decision with consultation with migrant family member 01

Male taking decision without consulting women of household

00 


\section{Results and Discussion}

\section{Determinants of rice production}

Agriculture was the main occupation of migrant households since more than 80 percent of their working adults were engaged in agricultural activities. Keeping in view the importance of agriculture, the present study examines the impact of migration on input use in rice cultivation which was principal crop in all the sample households under study. Analysis has been done for migrant and non-migrant households separately.

The values of $\mathrm{R}^{2}$ are worked out to be 0.9130 and 0.8750 which indicate that the variables included in analysis explain $91.30 \%$ and $87.50 \%$ variations in output (Y) on migrant and non migrant households, respectively. Regression Coefficient of land and capital are positive and statistically significant at one degree of probability on both categories of households, indicating that the potential of these factors of production are still to be exploited on migrant and nonmigrant households (Table-I).

On the other hand, regression co- efficients of labour and irrigation are positive and statistically significant on migrant households but regression co-efficient of these two factors were negative on non- migrant households. Hence it may be inferred that the migrant households have utilized human labour and irrigation resources more judiciously than non migrant households in rice cultivation. The observation suggests that the migration might have helped judicious use of human labour at native place due to migration of surplus labour force for gainful employment to destination places Migrant households were also found rational in use of irrigation resource since more than 90 percent migrant households purchased irrigation water from fellow farmers at an exorbitant rate (Rs. 60 to 80/ hr). Moreover, the higher input efficiency of inputs in rice cultivation on migrant households has been attributed to modern agricultural technologies also which were brought by migrant labours particularly improved seeds of rice, transplanting technique. (two to three rice seedlings in are situ. 
Table:-1 Regression Co-efficients of main factors of production in Rice cultivation in Bihar, India

\begin{tabular}{|l|l|l|l|l|}
\hline \multirow{2}{*}{ Variable } & \multicolumn{2}{c|}{ Migrant households } & \multicolumn{2}{c|}{ Non-migrant households } \\
\cline { 2 - 5 } & $\begin{array}{c}\text { Regression } \\
\text { Coefficient }\end{array}$ & $\begin{array}{c}\text { Standard } \\
\text { Error }\end{array}$ & $\begin{array}{c}\text { Regression } \\
\text { Coefficient }\end{array}$ & $\begin{array}{c}\text { Standard } \\
\text { Error }\end{array}$ \\
\hline Intercept & $4.5716^{* * *}$ & 0.5943 & 5.5874 & 0.7524 \\
\hline Land (Ha.) & $0.681^{* * *}$ & 0.0796 & 0.6436 & 0.095 \\
\hline Labor (prepays) & $0.1177^{*}$ & 0.0706 & -0.0264 & 0.0662 \\
\hline Capital (Rs.) & $0.3531^{* * *}$ & 0.0797 & 0.3157 & 0.071 \\
\hline Bullock (Rs.) & 0.0005 & 0.0045 & 0.0033 & 0.0054 \\
\hline Machinery (Rs.) & 0.0042 & 0.0042 & 0.0075 & 0.0044 \\
\hline Irrigation cost (Rs.) & $-0.0102^{* *}$ & 0.0042 & -0.0243 & 0.0092 \\
\hline $\begin{array}{l}\text { Number of } \\
\text { observations }\end{array}$ & 136 & & 183 & \\
\hline $\mathrm{R}^{2}$ & 0.91 & & & 0.87 \\
\hline
\end{tabular}

Note: $* * *, * *, *$ denote $1 \%, 5 \%$ and $10 \%$ level of significance.

\section{Use of Remittances}

Remittances are, no doubt, an important source of income on migrant households since it contributed 45 percent of total income of migrant households. It is worth pointing out that the annual average income of households of migrant households (Rs. 41,156) was higher than the income of comparable non migrant households in study villages. We examined the use of remittances in different activities which ultimately affects the livelihood of migrant households. It has been observed that a substantial amount of remittances are used for food (31\%) (Table-2). In the study area, food security is threatened due to recurrent flood, small size of holdings and larger proportion of low land and deep water area which are responsible for low productivity of food grains. The second important item of expenditure was construction and repair of residential houses $(17 \%)$. It was expected also because area is flood prone and every year it is almost necessary to repair the house in the study villages. In case of surplus money over routine expenses, the construction, repair and modification of houses is the first priority, because maintaining a good house is one of status symbols in rural area. Moreover, the residential facility 
is much poor in study villages and it seems to be a necessity to have good residential facility in these villages.

Table:-2 Use of Remittances for different purposes, Bihar, India

\begin{tabular}{|l|c|}
\hline Allocation of remittances & Percent to total \\
\hline Food & 31 \\
\hline Education of children & 4 \\
\hline Medicines & 8 \\
\hline Social functions & 6 \\
\hline Household construction/ maintenance & 17 \\
\hline Farm inputs & 7 \\
\hline Clothing & 9 \\
\hline Credit repayments & 4 \\
\hline Savings and investment & 14 \\
\hline \multicolumn{1}{|c|}{ Total } & 100 \\
\hline Average monthly income of migrant (Rs.) & 4539.00 \\
\hline Average monthly remittances sent (Rs.) & 1790.00 \\
\hline Percent of income sent as remittance & 39 \\
\hline
\end{tabular}

Remittances are also utilized for education of children and about one-tenth of remittances was allocated on medicines, indicating poor health of family members of the migrant households since a large proportion of population is malnourished in study villages. A substantial proportion of remittances $(9 \%)$ were allocated to clothing and dress materials. Allocation of remittances on education, medicines and clothing indicates that the migration is directly influencing the education level of children, health and standard of living in study villages.

Despite the inadequate remittances, about one-fifth of remittances were either invested in long-term assets or saved for future to meet the uncertainties. Hence, they prefer to save to meet their requirements in unforeseen situation arises due to natural calamities, unemployment, and illness. Hence, migration is a part of risk coping strategy for the weaker sections of the society. Hence, it may be said that the migration might have developed the habit of savings on migrant 
households There are evidences that migrant households of weaker sections invested their remittances on purchase of small piece of homestead land, livestock, and household durables.

The remittances are also used for repayment of loan but the amount allocated for this purpose was small (8\%). The migration through remittances is influencing positively the children education, food security, living conditions and standard of living in study villages.

\section{Women Empowerment}

Women empowerment has become popular in the development field since 1980s. It is vividly recognized that women empowerment is essential for sustainable economic growth and reduction in poverty in developing countries (Klasen, 1999). Although women empowerment is not a sufficient condition, it is still a necessary condition for development process. In the World Bank Policy Research Report, it is unambiguously suggested that women empowerment is being progressively recognized as an important policy goal for improving not just the well-being of women themselves but also for its positive impact on the family (King and Mason, 2001). Economically empowered women play a more active role in household decision-making, with greater bargaining power to increase spending on education and health (DFID, 2007).

Since women empowerment is an imperative part of development process, it also faces different challenges because of its specific regional and religious attributes in the country like India. Migration has opened a new opportunity to take decisions and responsibilities in household management in absence of male member. As migrants comprise of the most productive force of the population, those left behind are aged people, children and women folk. In the absence of active members it is the women who are required to take responsibility of households and take decision related to farming and domestic activities.

The relevant information were obtained from women of migrant and non migrant households under study which are computed and average scores are presented in Table-3. It has been observed that the women of migrant households are more empowered in taking agricultural and other household decisions than women of non migrant households

Women of all the category of households have stake in decision making in post harvest operations but women of migrant households had more stake in taking decision in post-harvest operations. Livestock farming was the second important activity where women empowerment 
was higher on migrant households. Moreover, the majority of migrants (89\%) belonged to backward and scheduled caste categories where women have been helping males in livestock management. They might have been more active is absence of their husbands/sons who had migrated to other places. Women of non-migrant households are less empowered in taking decisions of livestock farming, mainly due to presence of males in the households who do not involve their women folk in activities out side home, particularly in decision making.

Decision about choice of the crops/ varieties was the third important activity related to farming where women of migrant households had more stakes in decision making than women of non-migrant households. However, this is the second important farming activity for women of non-migrant households also with respect to their involvement in decision making. The main reason for participation of women in decision making for selecting crops/ varieties on all categories of households is their monopoly in cooking food for the family which probably empowers them to select crops/ varieties. Similar trend of women empowerment has been observed in crop management and purchase of inputs. Women of migrant households were also empowered to take decisions related to children's education and cash management than women of non-migrant households.

The higher score of empowerment indices supports this opinion that role of women has changed from a mere family worker to a manager. The change of women's role was more evident in nuclear family households where husband have migrated. In joint families, migration did not have much influence on role of women, because the head of the joint family generally takes the responsibility of decision-making. In case of migration of male members, other males of the family such as brothers or sons took the rein of household.

Caste was found to be an important contributing factor for changing role of women in migrant households. In majority of lower caste households, the changes in women role from worker to manager were observed. Moreover, nuclear family system was common in lower caste households. This reflects the changes taking place in role of women from family worker to manager in migrant households; but the process is more pronounced on nuclear families, lower caste, and weaker section households. 
Table:-3 Empowerment Indices of women of migrant and Non migrant households

Bihar, India

\begin{tabular}{|l|c|c|}
\hline Decision making issues & Migrant households & Non-migrant households \\
\hline Agricultural decisions & & \\
\hline Choice of crops & 02.59 & 02.00 \\
\hline Crop management & 02.15 & 01.60 \\
\hline Purchase of inputs & 02.14 & 01.66 \\
\hline Livestock rearing & 02.18 & 01.71 \\
\hline Post-harvest operations & 02.75 & 02.19 \\
\hline Other managerial decisions & & 01.76 \\
\hline Cash management & 02.09 & 01.86 \\
\hline Education of children & 02.15 & 01.52 \\
\hline Voting in elections & 01.94 & \\
\hline
\end{tabular}

\section{Problem of women in migrant households}

Process of shifting role of women from worker to manager of the households due to migration has also been observed, but there are several thorns in the crown. Women face several managerial, economic, social and personal problems, due to absence of male members of family. They have been facing more problems in day to day work. For example, in absence of male family members of the household, hiring of labour is routine work but necessary activity for cultivation. More than one-fourth of female respondents of migrant households felt problem in hiring labour for cultivation. The peak time scarcity of labour was common cause of hiring labour in villages where incidence of migration was at a large scale.

Lower caste migrant households had problems because labours of the relatively high caste (medium castes) hesitate to work on farms of lower caste households. Whereas females of forward caste have poor rapport with laborers of the village since they do not go out from the home due to social taboos and faced problem in hiring labour, however, the majority of female respondents did not face any problem since other family members and neighbors helped them in hiring labour for cultivation purposes. 


\section{Changes in workload}

Women work participation rate is low in Bihar (14\%) but almost all the adult women are engaged in household activities that are not considered as work by the Census of India. Moreover women of backward caste and all the scheduled caste categories are engaged in crop production and livestock activities in study villages. Women are engaged for 8-16 hrs in a day in economic and household activities (Om Prakash 1995). The migration of young and productive male members might have some influence on work load to women in study villages. This aspect has not the attracted the attention of researchers hence there is no report regarding change of work load to women of household who are left behind at native place due to migration of their male family members.

In present section, the changes in the workload on the basis of empirical evidences obtained from migrant households has been examined, particularly in rice production, however, the information generated through multiple questions asked to female members of respondent households are also utilized to reach at meaningful conclusions. Since labour migration is predominantly male oriented phenomenon, female labour is likely to compensate the decline in male labour force at their native places; consequently the work load of female workforce may increase in villages with high incidence of migration. Moreover, the increase in female workload is more pronounced on migrant households. It has been observed that per hectare family female labour use in modern rice production was higher on migrant households than non-migrant households in villages under investigation (Table-4).

Female workers of the family in migrant households worked more number of days than the male members of the family in rice production in study villages. This clearly indicates that the workload to females of migrant households increased enormously due to migration of male members in family. About one-third of women respondents reported that their workload increased, mainly due to migration of male members from the households. However, increased labour wage was also an important reason for increase in work load to women. It may therefore be inferred that the workload to female increased due to male migration, mainly for females of weaker section of society. There is almost no affect of male migration on workload to women in comparatively rich households. The work load to children of the households also increased due to migration of male family members of the household. Children help mainly in transplanting, 
weeding and raising cattle. However, female child helped the adult female in household work since adult females were generally engaged in field work, due to absence of male members of the family.

Table:-4 Labour used (person days/ha) in the production of modern rice varieties in sample villages Bihar, India

\begin{tabular}{|l|c|c|c|c|c|c|c|c|}
\hline \multicolumn{1}{|c|}{$\begin{array}{l}\text { Migrant/ } \\
\text { Activity }\end{array}$} & \multicolumn{3}{|c|}{ Family } & Exchange & \multicolumn{3}{c|}{ Hired } & All \\
\hline & MA & FA & Total & MA & MA & FA & Total & \\
\hline $\begin{array}{l}\text { Seed bed } \\
\text { preparation }\end{array}$ & 02.57 & 00.09 & 02.66 & - & 06.26 & - & 06.26 & 08.92 \\
\hline $\begin{array}{l}\text { Land } \\
\text { preparation }\end{array}$ & 04.59 & 01.41 & 06.00 & - & 20.10 & 01.76 & 21.86 & 27.86 \\
\hline $\begin{array}{l}\text { Crop } \\
\text { establishment }\end{array}$ & 03.92 & 06.37 & 10.29 & - & 14.52 & 13.91 & 28.43 & 38.72 \\
\hline Crop care & 13.35 & 11.69 & 25.03 & - & 01.41 & 26.80 & 28.21 & 53.24 \\
\hline Harvesting & 02.11 & 04.48 & 06.59 & - & 02.37 & 18.72 & 21.09 & 27.68 \\
\hline $\begin{array}{l}\text { Post harvest } \\
\text { activities }\end{array}$ & 09.50 & 14.63 & 24.13 & - & 09.53 & 00.26 & 09.79 & 33.93 \\
\hline All activities & 36.04 & 38.66 & 74.70 & - & 54.20 & 61.45 & 115.65 & 190.34 \\
\hline $\begin{array}{l}\text { Non- } \\
\text { Migrant }\end{array}$ & & & & & & & & \\
\hline $\begin{array}{l}\text { Seed bed } \\
\text { preparation }\end{array}$ & 05.02 & 00.06 & 05.08 & - & 04.55 & 00.04 & 04.59 & 09.67 \\
\hline $\begin{array}{l}\text { Land } \\
\text { preparation }\end{array}$ & 07.71 & 00.01 & 07.72 & 00.01 & 12.12 & 01.73 & 13.85 & 21.59 \\
\hline $\begin{array}{l}\text { Crop } \\
\text { establishment }\end{array}$ & 10.27 & 02.13 & 12.40 & 00.62 & 17.62 & 11.13 & 28.75 & 41.77 \\
\hline Crop care & 15.58 & 08.52 & 24.09 & 00.03 & 03.85 & 06.49 & 10.34 & 34.46 \\
\hline Harvesting & 03.73 & 03.05 & 06.78 & - & 14.02 & 09.10 & 23.12 & 29.92 \\
\hline $\begin{array}{l}\text { Post harvest } \\
\text { activities }\end{array}$ & 10.94 & 11.70 & 22.64 & 00.74 & 11.08 & 01.85 & 12.93 & 36.31 \\
\hline All activities & 53.24 & 25.47 & 78.71 & 01.40 & 63.26 & 30.34 & 93.60 & 173.72 \\
\hline
\end{tabular}

MA- Male adult, FA- Female adult

\section{Conclusions}

Migration of male labour force from Bihar has increased during last two decades which prompted us to analyze its consequences on efficiency of input in agricultural production, livelihood through remittances and also the empowerment of women left behind at place of origin. It was observed that the efficiencies of human labour and irrigation in rice production 
were higher than non-migrant households and statistically significant, indicating rational use of these two critical inputs on migrant households in Bihar. The migration seems to have helped in judicious use of human labour at native place due to migration of surplus labour force for gainful employment to destination of migration. Remittances have been utilized for meeting consumption needs, improved livelihood, better education to children and better health care facilities which help in overall improvement in livelihood on migrant households in Bihar. Migrant households also preferred to save money to meet their requirements in unforeseen situations. It can thus be infered that migration may be one of risk-coping strategies for the weaker sections of the society and has helped developing the saving habits among migrant households. The allocation of remittances on agricultural inputs could have increased if proper infrastructure facilities were present in rural areas for faster dissemination of modern agricultural technology for increasing agricultural production. Level of women employment has increased on migrant households, particularly on poor households; however, work load of women has also increased. It has been observed that role of women of migrant households changed from unpaid female labour to managers of the household, however, they face problem in management of fund, technology and input-output marketing. There is a need to launch a programme for their training to improve their knowledge in financial, technological and marketing management.

\section{References}

Bague, D.J. (1969), Principle of Demography, New York.

Chaudhry, Imran Sharif and Nosheen, Farhana. (2009). The Determinants of Women Empowerment in Southern Punjab (Pakistan): An Empirical Analysis. European Journal of Social Sciences - Vol.10, No. 2.pp.216-229.

DFID. (2007).Gender Equality Action Plan 2007-09 making faster progress to gender Equality. A DFID Practice Paper.U.K.

Jha, A. K., Singh, Krishna M., Meena, M. S. and Singh, R. K. P. (2012). Constraints of Rainfed Rice Production in Eastern India: An Overview. Available at: http://dx.doi.org/10.2139/ssrn.2061953

Kabir, Naila. (1999). Resource, Agency Achievements: Reflections on the Measurement of Women Empowerment. Development and Change. Vol.30. 435-464.

Kabeer, Naila. (2005). Gender Equality and Women's Empowerment: A Critical Analysis of the Third Millennium Development Goal. Gender and Development. Vol.13, No.-1. pp.1324. 
King, Elizabeth and Mason Andrew (2001). Engendering Development: Through Gender Equality in Rights, Resources, and Voice. World Bank Policy Research Report, Washington, D.C.

Klasen, S. (1999). Does Gender Inequality Reduce Growth and Development? Evidences from the Cross-country Regressions. Policy Research Report on gender and Development. Paper series no. 7, The World Bank, Washington, D.C.

Lewis, A (1994) Economics of Development with unlimited supplies of Labour, The Economics of under development. Ed: Agrawal, AN. And Singh, S.P), Oxford Press, New Delhi.

Om Prakash (1950) A study on Women work participation in East Champaran district, Bihar. Post Graduate Thesis, Rajendra Agricultural University, Bihar, Pusa, Samastipur.

Rozelle, S, Taylor, J.E and Debrauw, A. (1999) Migration, Remittances and Agricultural productivity in China. American Economic Review, Vol. 89. No. 1-2

Stark, O (1991) The migration of Labour, Cambridge, MA, Blackwell.

Singh, R. K. P., Singh, K. M., \& Jha, A. K. (2012). Effect of Migration on Agricultural Productivity and Women Empowerment in Bihar. Labor: Demographics \& Economics of the Family eJournal Vol 4, Issue 73, July 31, 2012. http://dx.doi.org/10.2139/ssrn.2111155.

Singh, Krishna M., Jha, A. K., Meena, M. S. and Singh, R. K. P., Constraints of Rainfed Rice Production in India: An Overview (2012). Innovations in Rice Production, Ed: P.K. Shetty, M.R. Hegde and M. Mahadevappa, National Institute of Advance Studies, Indian Institute of Science Campus, Bangalore, pp. 71-84, 2012. Available at: http://dx.doi.org/10.2139/ssrn.2210401

Singh, Krishna M., Meena, M. S., Kumar, Abhay and Singh, R. K. P. (2013). An Overview of Gender Issues in Agriculture. Available at: http://dx.doi.org/10.2139/ssrn.2237993

Singh, K. M., Meena, M. S., Kumar, A., \& Singh, R. K. P. (2012). Dimensions of Poverty in Bihar. Development Economics: Regional \& Country Studies eJournal, Vol 1, Issue 13, May 04, 2012. Available at: http://dx.doi.org/10.2139/ssrn.2017506 